\title{
Maturity and spawning of Secutor insidiator along the Kerala coast
}

\author{
${ }^{1}$ K. J. Abraham, ${ }^{2}$ V. S. R. Murty and ${ }^{* 2}$ K. K. Joshi \\ ${ }^{1}$ Department of Zoology and Aquaculture, St Xavier's College, Vaikom, Kerala, India \\ ${ }^{2}$ Central Marine Fisheries Research Institute, P.B.No.1603, Kochi-682 018, India \\ *E-mail: joshycmfri@ rediffmail.com
}

\begin{abstract}
The reproductive biology of Secutor insidiator $(\mathrm{N}=1546)$ was studied from samples collected along Kerala during October 1998-December 1999. A separate scale of five stages of maturity has been developed. Analysis of data on the ova of different stages of maturation in different length groups and months showed that spawning takes place in batches regularly at intervals after the juveniles undergo the process of maturation and reach ripe stage. The length at first maturity was estimated at $75 \mathrm{~mm}$. This species has a protracted spawning season extending almost throughout the year.
\end{abstract}

Keywords: Maturity stages, silverbellies, length at maturity, spawning, fecundity, gonadosomatic index

\section{Introduction}

The process of spawning in fish is influenced by internal and external factors. The internal factors, which induce maturation and spawning, are the hormones. Among different external factors, temperature were considered important for spawning (Murty and Edelman, 1968; Qasim 1973; Bensam, 1999). Usually in marine fishes, the spawning process is accompanied by shoaling, when contents of the male and female gonads are released into the water where fertilization occurs. Often, spawning of one individual induces others to follow and the presence of sperms in water is known to induce the females to shed their eggs.

In silverbellies, several studies were made on maturation and spawning along the east coast of India (Arora, 1952; Balan, 1963; Rao, 1967; Pillai,1972; James and Badrudeen, 1975, 1981, 1986; Murty, 1983, 1990; Jayabalan and Ramamurthy, 1985; James, 1986; Jayabalan, 1986). However, there are no such studies from the west coast of India. The present study was undertaken to understand maturation and spawning of $S$. insidiator along the Kerala coast.

\section{Material and Methods}

A total of 1546 specimens of $S$. insidiator (length range: $47 \mathrm{~mm}$ to $111 \mathrm{~mm}$ ) were collected fortnightly during October 1998 - December 1999 from Cochin and Neendakara Fisheries Harbour. After measuring the length and weight of each specimen, the belly was cut open to note the sex, colour and general appearance of the gonads, which were then carefully removed and preserved in 5\% formalin, in labelled bottles. Since spawning is synchronous in the population (Arora, 1952; Balan, 1963), analysis on maturation and spawning was carried out essentially on the ovaries only.

Quantification of ovaries into different stages of maturation: The appearance of ovaries in fresh condition, the proportion of area occupied by them in the body cavity and the structure and diameter range of the intra-ovarian ova were considered for quantification of ovaries into different stages of maturation.

Determination of length at first maturity: For determining the length at first maturity $\left(\mathrm{L}_{\mathrm{m}}\right)$, specimens with ovaries in stages IV and V of maturation were considered as mature and the proportion of mature fish in each length group was 
determined. Maturity curves were drawn to scatter plots. The length at which about $50 \%$ of the fish are mature, has been taken as the $\mathrm{L}_{\mathrm{m}}$. To determine length at first maturity, spawning and peak spawning seasons alone were considered as almost all the adult fish during these seasons are expected to be in mature stage. This approach eliminated the possibility of growth influencing the estimate of length at first maturity.

Spawning: The periodicity of spawning was determined using ova diameter frequency distribution in mature ovaries following Hickling and Rutenberg (1936) and De Jong (1940).

The distribution of sexes and maturation stages in fishes of different length groups in the samples were weighted to obtain distribution in the total catch of the species in each month at Cochin and Neendakara Fisheries Harbours. The estimates thus obtained from these centres were pooled. The spawning period was determined using data on maturation stages in different months and the months of occurrence of gravid fishes were taken as the spawning period. For this purpose only fishes on and above the length at first maturity were considered. The gonadosomatic index was determined using the following formula.

Gonadosomatic Index $=\frac{\text { Gonadal weight }}{\text { Body weight }} \times 100$

\section{Results and Discussion}

\section{Maturation}

i. Description of ovaries and ova: The ovaries of S. insidiator are rounded unpaired, lying in the middle of the body cavity attached to the dorsal wall. The mature ovary is compact, more or less spherical and occupies the bulk of the body cavity. It is bright yellow in colour with ova of different sizes. Four groups of ova are distinguished in ripe ovaries:

Type I (Immature ova): Irregular shape, a few larger ova spherical, translucent, yolkless, nucleus clearly visible; ova diameter ranges from $3.3 \mu \mathrm{m}$ to $13.5 \mu \mathrm{m}$.

Type II (Maturing ova): More or less spherical in shape, almost opaque. Nucleus not visible, ova diameter ranges from $13.5 \mu \mathrm{m}$ to $37.1 \mu \mathrm{m}$.
Type III (Mature ova): Spherical in shape; opaque due to deposition of yolk; a clear space present around the periphery, ova diameter ranges from 27.0 $\mu \mathrm{m}$ to $49.5 \mu \mathrm{m}$.

Type IV (Ripe ova): Ova large and spherical, translucent, a large fat globule present; ova diameter above $43.8 \mu \mathrm{m}$.

ii. Maturation stages: The following five maturation stages were categorised:

Stage I (Immature female): Ovaries occupy $1 / 4^{\text {th }}$ of the body cavity, pale yellow and translucent in appearance. The ova diameter ranges from 2.25 to $10.1 \mu \mathrm{m}$.

Stage II (Immature female): Ovaries occupy less than $1 / 3^{\text {rd }}$ of the body cavity. Pale yellow and translucent in appearance. Eggs could be slightly made out with the naked eye on teasing the ovary. Ova diameter ranges from $3.37 \mu \mathrm{m}$ to $13.5 \mu \mathrm{m}$ with a mode at $6.75 \mu \mathrm{m}$.

Stage III (Maturing female): Ovaries occupy 1/ $3-1 / 2$ of the body cavity, eggs visible with the naked eye, yellow in colour. Ova diameter ranges from 13.5 $\mu \mathrm{m}$ to $37.12 \mu \mathrm{m}$ with the modal class at $30.3-33.7$ $\mu \mathrm{m}$.

Stage IV (Mature female): Ovaries occupy $1 / 3$ $3 / 4$ of the body cavity, yellow in colour. Eggs granular and clearly visible in the ovary. Ova diameter ranges from $27.0 \mu \mathrm{m}$ to $50.6 \mu \mathrm{m}$ with the mode at 37.12 $\mu \mathrm{m}$.

Stage V (Ripe female): Ovaries occupy $3 / 4$ to nearly full body cavity, bright yellow in colour. Translucent eggs clearly visible in the ovary. Ova diameter ranges from $43.8 \mu \mathrm{m}$ to $79.87 \mu \mathrm{m}$ with the modal class at $54-57.3 \mu \mathrm{m}$.

For classifying maturity stages of ovary, the International Council for the Exploration of the Sea (ICES) recognised seven stages, which were assigned by Wood (1930) for the herring. This classification was followed by several Indian researchers for different species (Seshappa and Bhimachar, 1955; Pradhan and Palekar, 1956; Dharmamba, 1959; Varghese, 1961; Balan, 1963; Rao, 1967; Sam, 1967; Antony, 1969; Devadoss, 1969; Marichamy, 1970; Kagwade, 1971; James and Badrudeen 1975; 
Jayabalan and Ramamoorthi, 1985; James, 1986; Jayabalan, 1986, 1988; Luther, 1986) to describe the maturity stages of fishes that are fractional spawners with prolonged spawning seasons. Jhingran (1961), Rao (1967b), James (1967), and Deshmukh (1973) also adopted this scale with slight modifications. However, the classification by ICES was primarily developed for fish of the temperate waters, with a short and restricted spawning period. Considering the problems associated with the classification of maturity stages, Qasim (1973) suggested the following five-point scale for tropical and subtropical fishes: I. Immature virgins, II. Maturing virgins or Recovered spents, III. Ripening, IV. Ripe and V. Spent. The chances of collecting a perfectly ripe fish are remote in the population of continuous breeders, as a part of ovary spawns before the ovary turns fully ripe. Hence, Qasim (1973) considered that it was desirable to include only three stages for the continuous breeders - I. Immature, II. Maturing and III Ripening.

In the present paper, scale of five stages has been suggested for classifying the gonads of $S$. insidiatoron the basis of external appearance of ovaries. The 'spent' stage has not been designated here since no such ovary was encountered in the present collections.

Length at first maturity: The length at maturity of $S$. insidiator based on the pooled data during September 99 - December 99 was 75 mm (Fig.1) and based on the data of one year was $80 \mathrm{~mm}$ (Fig. 2 ). The length at first maturity obtained during the peak spawning period can be more accurate as it avoids the over representation of the immature and maturing fish in the sample. The length at first maturity of $S$. insidiator from Port Novo, was estimated as 76 - $91 \mathrm{~mm}$ for females (Jayabalan and Ramamoorthi, 1985), since all females up to $75 \mathrm{~mm}$ were immature and all the fishes above $90 \mathrm{~mm}$ were in mature condition. Murty (1990) estimated the length at first maturity of $S$. insidiator as $90 \mathrm{~mm}$, with mature gonads occurring from length of $72 \mathrm{~mm}$ onwards.

\section{Spawning}

i. Gonadosomatic index (GSI): In the present study, gonadosomatic index was used to corroborate

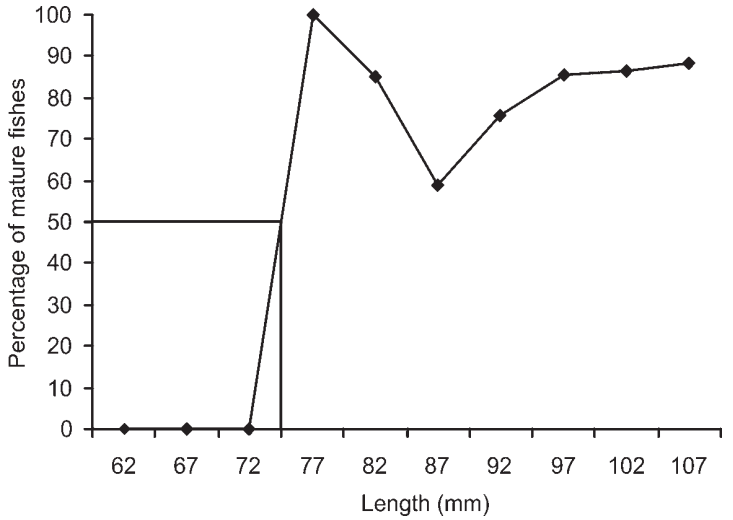

Fig. 1. Proportion of mature fishes in different length groups in $S$. insidiator (based on data during September 1999-December 99)

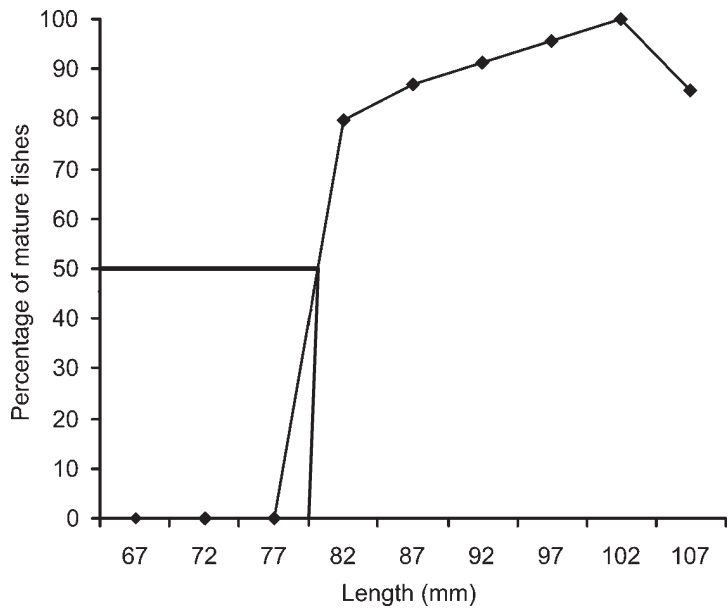

Fig. 2. Proportion of mature fishes in different length groups in S. insidiator (based on data during 1998 - 1999)

the spawning period as estimated from the percentage occurrence of maturity stages. For the studies on gonadosomatic index, only fishes above the length at first maturity were considered. The GSI for the different maturity stages of $S$. insidiator are presented in Table 1. The GSI was found to increase from 0.4049 in stage I females to 2.9164 in stage V females. High GSI values during March-April 1999 and September-December 1999 coincided with peak periods of spawning activity (Fig. 3).

ii. Occurrence of gravid fishes: In S. insidiator, mature adults occurred during all months (Table 2) 
Table 1. Gonadosomatic Index in S. insidiator female of different stages of maturation (average values with standard deviation)

\begin{tabular}{clc}
\hline $\begin{array}{c}\text { Stages of } \\
\text { maturity }\end{array}$ & $\mathrm{n}$ & GSI \\
\hline I & 16 & $0.4049 \pm 0.2923$ \\
II & 6 & $0.3142 \pm 0.1723$ \\
III & 191 & $1.4308 \pm 0.7804$ \\
IV & 570 & $2.3546 \pm 0.7832$ \\
V & 1 & $2.9164 \pm 0.4889$ \\
\hline
\end{tabular}

with occurrence exceeding 90\% in March-April and September-December. Fishes with ripe, running stages were rare. This may be due to several reasons; in many marine species the ripe stage is of a very short duration and in some cases lasting only for a few hours. On the basis of occurrence of mature females in almost all months, it is reasonable to conclude that $S$. insidiator has an extended spawning period almost throughout the year.

Pillai (1972) indicated a prolonged spawning period for $S$. insidiator from the presence of juveniles in shore seine catches from Mandapam for most part of the year. Jayabalan and Ramamoorthi (1985), from the study of the percentage occurrence of different stages of maturity of female gonads, indicated that the spawning of $S$. insidiator takes place between

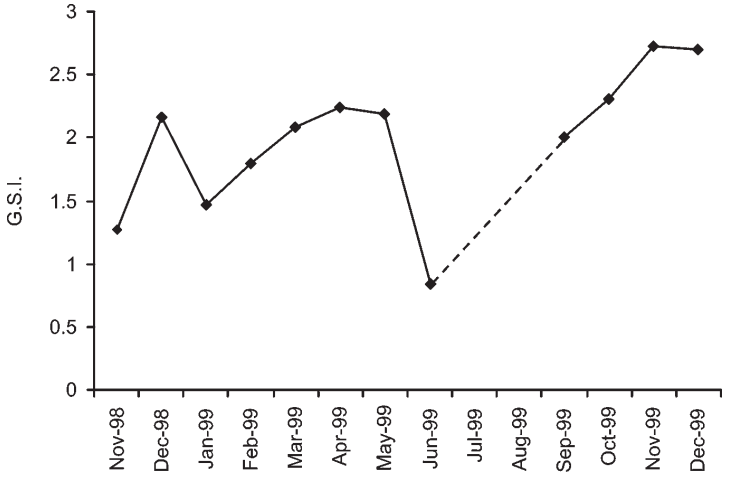

Fig. 3. Gonadosomatic Index (GSI) in females of $S$. insidiator in different months

July and November and again during March and April at Porto Novo coast. James and Badrudeen (1986) concluded from the ova diameter frequency curve of the mature ovary that in $S$. insidiator, the maturation process is continuous and that the species is likely to spawn over a prolonged period at Mandapam. Murty (1990) was also of the same opinion, asserting that the spawning season is almost throughout the year, with a peak during January to March at Kakinada. It may be concluded from the present study that $S$. insidiator has a protracted spawning season along the Kerala coast, extending almost throughout the year.

Table 2. Distribution (in percentage) of females in different stages of maturation in S. insidiator

\begin{tabular}{|c|c|c|c|c|c|c|}
\hline \multirow[b]{2}{*}{ Month } & \multirow[b]{2}{*}{$\begin{array}{l}\text { No. of females } \\
\text { examined (n) }\end{array}$} & \multirow[b]{2}{*}{$\mathrm{I}$} & \multicolumn{3}{|c|}{ Maturity Stages (percent) } & \multirow[b]{2}{*}{$\mathrm{V}$} \\
\hline & & & II & III & IV & \\
\hline October 1998 & 29 & 0 & 0 & 52.8 & 47.2 & \\
\hline November & 33 & 0 & 0.3 & 12 & 87.7 & \\
\hline December & 40 & 0 & 0 & 44.3 & 55.7 & \\
\hline January 1999 & 173 & 1.9 & 0.3 & 58.2 & 39.6 & \\
\hline February & 39 & 2.4 & 0 & 25.8 & 71.8 & \\
\hline March & 82 & 0 & 0 & 9.5 & 90.5 & \\
\hline April & 96 & 1.1 & 0 & 5.1 & 92.2 & 1.6 \\
\hline May & 25 & 0 & 0 & 0 & 100 & \\
\hline June & 34 & 24.9 & 16.1 & 46 & 13 & \\
\hline July & & & No fi & & & \\
\hline August & & & No la & & & \\
\hline September & 28 & 0 & 0 & 7.8 & 92.2 & \\
\hline October & 78 & 2.5 & 0 & 3.1 & 94.4 & \\
\hline November & 72 & 0.9 & 0 & 7.3 & 91.9 & \\
\hline December & 57 & 0 & 0 & 9.2 & 90.8 & \\
\hline
\end{tabular}




\section{Acknowledgements}

The authors are very grateful for the encouragement and support given by Director, C.M.F.R.I. The authors also wish to express sincere thanks to Dr. Sathish Sahayak and Shri. N. Rudramurty for their help and support.

\section{References}

Antony, R. B. T. 1969. The Indian oil sardine. Bull. Cent. Mar. Fish. Res. Inst., 16: 128 pp.

Arora, H. L. 1952. Contributions to the biology of the silverbelly Leiognathus splendens (Cuv.). Proc. IndoPacific Fish.Counc. 3, Tech. Pap., 4: 75-80.

Balan, V. 1963. Biology of the silverbelly, Leiognathus bindus (Val.) of the Calicut coast. Indian. J. Fish., 10: 118-134.

Bensam, P. 1999. Development of Marine Fisheries Science in India. Daya Publishing House, 379 pp.

De Jong, J. K. 1940. A preliminary investigation of the spawning habits of some fishes of the Java Sea. Treubia, 17: 307-327.

Deshmukh, V. M. 1973. Fishery and biology of Pomadasys hasta (Bloch). Indian J. Fish., 20(2): 497-522.

Devadoss, P. 1969. Maturity and spawning in Otolithus ruber (Schn.) and Johnius dussumieri (C. and V.). Indian J. Fish., 16 (1\&2): 117-128.

Dharmamba, M. 1959. Studies on the maturation and spawning habits of some common clupeoids of Lawson's Bay, Waltair. Indian J. Fish., 6: 374-388.

Hickling, C. F. and E. Rutenberg. 1936. The ovary as an indicator of the spawning period in fishes. J. Mar. Biol. Ass. U. K., 21: 311-317.

James, P. S. B. R. 1967. Leiognathus leuciscus (Gunther) and Leiognathus smithursti (Ramsay and Ogilby) (Family: Leiognathidae: Pisces) - Two new records from the Indian seas. J. Mar. Biol. Ass. India, 9(2): 300-302.

James, P. S. B. R. 1986. Biology and fishery of Leiognathus jonesi James from the Palk Bay and Gulf of Mannar. In: P. S. B. R. James (Ed.) Recent Advances in Marine Biology. Today and Tomorrow Publishers, New Delhi, p. 29-101.

James, P. S. B. R. and M. Badrudeen. 1975. Biology and fishery of Leiognathus brevirostris (Valenciennes) from the Palk Bay and Gulf of Mannar. Indian J. Mar. Sci., 4: 50-59.
James, P. S. B. R. and M. Badrudeen. 1981. Biology and fishery of silverbelly Leiognathus dussumieri (Valenciennes) from Gulf of Mannar. Indian J. Fish., 28(1\&2): 154-182.

James, P. S. B. R. and M. Badrudeen. 1986. Studies on maturation and spawning of the fishes of the family Leiognathidae from the seas around India. Indian $J$. Fish., 33(1): 1-26.

Jayabalan, N. 1986. Reproductive biology of silverbelly Leiognathus splendens (Cuvier) from Porto Novo. Indian J. Fish., 33(2): 171-179.

Jayabalan, N. 1988. Reproductive biology of the pony fish Gazza minuta (Bloch) from Porto Novo, east coast of India. Indian. J. Mar. Sci., 17(1): 51-54.

Jayabalan, N. and K. Ramamoorthi. 1985. Maturation and spawning of silverbelly Secutor insidiator from Porto Novo coast. Indian. J. Mar. Sci., 14: 105-150.

Jhingran, A. G. 1961. Studies on the maturity and the fecundity of the Gangetic anchovy, Setipinna phasa (Hamilton). Indian J. Fish., 8(2): 291-311.

Kagwade, V. N. 1971. Maturation and spawning of the horse mackerel Caranx kalla (Cuv. \& Val.). Indian J. Fish., 15: 207-220.

Luther, G. 1986. Studies on the biology and fishery of the fishes of the genus Chirocentrus Cuvier IV. Reproduction. In: P. S. B. R. James (Ed.) Recent Advances in Marine Biology. Today and Tomorrow Publishers, New Delhi, p. 439-512.

Marichamy, R. 1970. Maturity and spawning of the anchovy, Thrissina baelama (Forsskål) from the Andaman Sea. Indian J. Fish., 17: 179-189.

Murty, V. S. 1983. Observation on some aspects of the biology of silverbelly Leiognathus bindus (Valenciennes) from Kakinada. Indian J. Fish., 30(1): 61-68.

Murty, V. S. 1990. Biology and population dynamics of the silverbelly Secutor insidiator (Bloch) from Kakinada. J. Mar. Biol. Ass. India, 32: 10-24.

Murty, A. V. S. and M. S. Edelman. 1968. On the relation between the intensity of the southwest monsoon and the oil sardine fishery of India. Indian J. Fish., 13(1\&2): 142-149.

Pillai, P. K. 1972. Fecundity and spawning habits of some silverbellies. Indian J. Fish., 19: 196-199.

Pradhan, L. B. and B. C. Palekar. 1956. Key to the stages of sexual maturity of Rastrelliger kanagurta. Indian J. Fish., 3: 183-185. 
Qasim, S. Z. 1973. An appraisal of the studies on maturation and spawning in marine teleosts from the Indian waters. Indian J. Fish., 20(1): 166181.

Rao, K. S. 1967. Reproductive cycles and lipid levels of Leiognathus splendens (Cuv.). J. Mar. Biol. Ass. India, 9(2): 303-322.

Rao, V. R. 1967. Spawning behaviour and fecundity of the Indian mackerel, Rastrelliger kanagurta (Cuvier) at Mangalore. Indian J. Fish., 14: 171186.
Sam, B. P. 1967. Some observations on the fishery and biology of Sardinella fimbriata (Val.) at Vizhinjam. Indian J. Fish., 14(1\&2): 145-158.

Seshappa, G. and B. S. Bhimachar. 1955. Studies on the fishery and biology of the Malabar sole Cynoglossus semifasciatus Day. Indian J. Fish., 2: 180-230.

Varghese, T. J. 1961. Observations on the biology of Raconda russelliana (Gray). Indian J. Fish., 8: 96-106.

Wood, H. 1930. Scottish herring shoals. Pre-spawning and spawning movements. Scotland Fish. Bd. Sci. Invest., 1: $1-71$.

Received : 18/11/2010

Accepted : 16/09/2011

Published : 15/12/2011 